\title{
Breeding of highly productive varieties of winter triticale resistant to pre-harvest germination of grain in the ear
}

\author{
Valentina Rubets ${ }^{1}$, Irina Voronchikhina ${ }^{2, *}$, Vladimir Pylnev ${ }^{1}$, and Viktor Voronchikhin ${ }^{2}$ \\ ${ }^{1}$ Federal State Budgetary Educational Institution of Higher Education "Russian Timiryazev State \\ Agrarian University", 127550, Moscow, Russian Federation \\ ${ }^{2}$ Federal State Budgetary Institution of Sciences the Main Botanical Garden named after N. V. Tsitsin \\ of Russian Academy of Sciences, 127276, Moscow, Russian Federation
}

\begin{abstract}
Creation of new varieties of winter hexaploid triticale for the central part of Russia is characterized by increased resistance of grain to germination on the root. The phenomenon of germination on the root is one of the limiting traits that limit the spread of triticale culture in areas of excessive moisture, which is the Central Region of the Non-Chernozem zone. The work was carried out at the Russian State Agrarian University Moscow Agricultural Academy named after K.A. Timiryazev in 20182019. Field experiments were conducted in the fields of the Field Experimental and Breeding Stations. Laboratory tests were carried out at the Department of Genetics, Breeding and Seed Production. As a result of a comprehensive assessment of breeding varieties in the preliminary variety testing, the most valuable sample of winter triticale $228 \mathrm{~h}$ (Castus $\mathrm{x}$ Don) was isolated, which formed a yield at the standard level, and during 3 years of study showed relatively high resistance to pre-harvest germination of grain in the ear. This sample is currently being intensively propagated for transfer to the State Variety Testing in 2020.
\end{abstract}

\section{Introduction}

Winter triticale is one of the most popular fodder crops in modern animal husbandry. It is characterized by a high potential and real yield, it is able to grow on low-fertile lands and at the same time give a relatively high yield of grain and green mass. Triticale grain forms the same amount of protein as wheat, but it has a higher digestibility in animals due to the reduced gluten content. In addition, triticale grain varies greatly in terms of technological qualities. There are varieties with high baking qualities, as well as those that are able to improve the baking qualities of wheat, increasing the gas-forming ability of its flour and giving a more fluffy bread when mixed with wheat flour [1-8].

Nevertheless, triticale also has disadvantages, one of the most significant of them is the pre-harvest germination of grain in the ear. This phenomenon is that the grain, being at different stages of maturity, is able to germinate in the ear during precipitation. There are

\footnotetext{
*Corresponding author: yarinkapanfilova@gmail.com
} 
two types of grain germination in the ear. Latent (initial) germination, when hydrolytic enzymes destroy high-molecular spare substances of the endosperm, converting them into a soluble state. At the same time, the embryo has no signs of germination. The visible germination of grain in the ear is characterized by the presence of germinated embryos to varying degrees. This phenomenon leads to a deterioration of both the technological qualities of grain and the sowing qualities of seeds $[9,10]$.

The creation of winter triticale varieties with a sufficient level of yield with reduced preharvest germination of grain in the ear is an urgent task for the region with excessive moisture, which is the Central region of the Non-Chernozem zone of Russia.

\section{Materials, methods and conditions of research}

The work was carried out at the Russian State Agrarian University - Moscow Agricultural Academy named after K.A. Timiryazev in 2018-2019. Field experiments were conducted in the fields of the Field Experimental and Breeding Stations. Laboratory tests were carried out at the Department of Genetics, Breeding and Seed Production.

The initial material for the research was varietal samples of winter triticale of various ecological and geographical origin, obtained from various sources (VNNIR named after N.I. Vavilov, MosNIISKh "Nemchinovka", NIISKh TsChP n.a. Dokuchaev et al.). On their basis, hybrids of different degrees of complexity were obtained (Table 1).

Since the breeding process is represented by a large number of diverse nurseries, we will give a detailed consideration of the breeding evaluations only for preliminary variety testing.

The registered area of the plot was $5 \mathrm{~m}^{2}$, the number of rows was 7 . The repetition is four-fold, the placement of options is randomized. Grain harvesting was carried out in the phase of full ripeness of winter triticale plants with a Sampo 130 selection combine. After harvesting, the grain was dried to a standard humidity of $14 \%$, after which it was weighed separately. The origin (breeding record) of the variety samples tested in the preliminary variety testing is presented in Table 1 .

The evaluation of breeding material in nurseries and variety testing was carried out according to the methodology of the State Commission of the Russian Federation for Testing and Protection of Breeding Achievements $[11,12,13]$.

During the growing season, the onset of phenological phases was noted, the overwintering of plants was evaluated, the resistance to lodging, to the main fungal diseases was evaluated, the yield (actual and potential) was evaluated, the physical and biochemical qualities of winter triticale grain were determined [12, 14, 17, 18].

Table 1. The origin of varietal samples in the preliminary variety testing of winter triticale.

\begin{tabular}{|c|c|c|}
\hline No. & $\begin{array}{c}\text { Hybrid combination } \\
\text { number }\end{array}$ & Hybrid combination decoding \\
\hline 1 & Timiryazevskaya 150 & standard \\
\hline 2 & $228 \mathrm{~h}($ perspective line $)$ & Castus $\times$ Don \\
\hline 3 & $219 \mathrm{~h}-1$ & Nemchinovsky $56 \times($ Doctrina $110 \times$ Garmonia) \\
\hline 4 & $219 \mathrm{~h}-2$ & Nemchinovsky $56 \times($ Doctrina $110 \times$ Garmonia $)$ \\
\hline 5 & $314 \mathrm{~h}$ & Victor $\times$ Don $) \times$ Don \\
\hline 6 & $287 \mathrm{~h}$ & Line $21759 / 97 \times($ Line $2 \times$ Stavropolsky 2$)$ \\
\hline 7 & $209 \mathrm{~h}-1$ & Victor $\times($ Fidelio $\times$ Doctrina 110$)$ \\
\hline 8 & Nemchinovsky 56 & Victor $\times($ Fidelio $\times$ Doctrina 110$)$ \\
\hline 9 & $209 \mathrm{~h}-2$ & Nemchinovsky $56 \times$ Valentin \\
\hline 10 & $303 \mathrm{~h}$ & Nemchinovsky $56 \times($ Doctrina $110 \times$ Garmonia $)$ \\
\hline 11 & $219 \mathrm{~h}-3$ &
\end{tabular}




\begin{tabular}{|c|c|c|}
\hline 12 & $391 \mathrm{~h}$ & {$[$ (Niklap $\times$ Strelna) $\times$ Garmonia $] \times$ Timiryazevskaya 150} \\
\hline 13 & $278 \mathrm{~h}-1$ & Valentin $\times($ MGR $1 \times$ Talva 100) \\
\hline 14 & $87 \mathrm{~h}-1$ & ADK8-45t 394-35 $\times$ Antey \\
\hline 15 & $87 \mathrm{~h}-2$ & ADK8-45t 394-35 $\times$ Antey \\
\hline 16 & $87 \mathrm{~h}-3$ & ADK8-45t 394-35 $\times$ Antey \\
\hline 17 & $87 \mathrm{~h}-4$ & ADK8-45t 394-35 $\times$ Antey \\
\hline 18 & $33 \mathrm{~h}-1$ & Zakarpatskaya mnogozernaya $\times$ Doctrina 110 \\
\hline 19 & $33 \mathrm{~h}-2$ & Zakarpatskaya mnogozernaya $\times$ Doctrina 110 \\
\hline 20 & $33 \mathrm{~h}-3$ & Zakarpatskaya mnogozernaya $\times$ Doctrina 110 \\
\hline 21 & $278 \mathrm{~h}-2$ & Valentin $\times($ MGR $1 \times$ Talva 100 $)$ \\
\hline
\end{tabular}

The meteorological conditions of the growing season of winter triticale were characterized by elevated average daily temperatures and uneven precipitation. The wintering conditions were relatively favorable. Nevertheless, the early spring drought in April against the background of high temperatures led to an acceleration of plant development, the absence or weak tillering, which, as a result, adversely affected the grain harvest.

Describing the meteorological conditions of the spring-summer vegetation that developed in 2018-2019, we can say that they were unfavorable both for the formation of high grain yield and high grain quality. Such conditions can be characterized as provocative for the pre-harvest germination of grain in the ear.

For the purposes of our research, such vegetation conditions are a differentiating background that allows to identify genotypes with deep and long dormancy of seeds and select forms resistant to germination on the root, without artificial provocation.

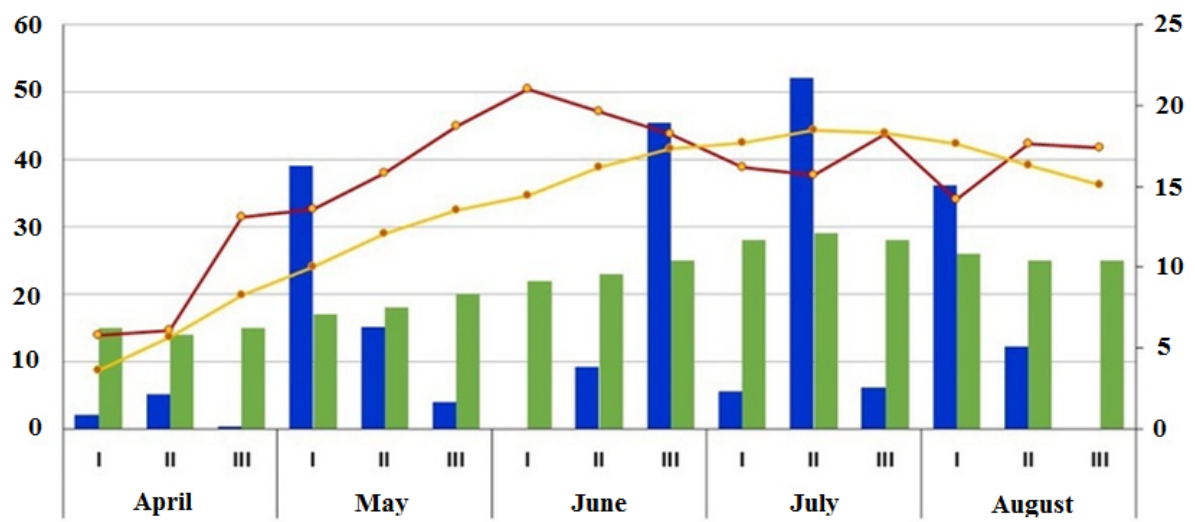

2019 amount of precipitation, $\mathrm{mm}$

$\approx 2019$ av. air temperature, ${ }^{\circ} \mathrm{C}$

- Average long-term data amount of precipitation, $\mathbf{m m}$

$\rightarrow$ Average long-term data av. air temperature, ${ }^{\circ} \mathrm{C}$

Fig. 1. The sub-decadal average daily air temperature of 2019 and the amount of precipitation of the growing season of 2019 (according to the observations of the Meteorological Observatory n.a. V.A. Michelson)

\section{Results and discussion}

Overwintering of winter crops is one of the main factors that ensure a high yield. Winter hardiness of winter crops depends on many factors, the main of which in the conditions of the central part of Russia are low temperatures and Fusarium mold damage. Winter triticale 
is resistant to low temperatures, and its successful overwintering depends on the degree of Fusarium mold damage.

Overwintering in the conditions of Moscow can occur under various meteorological conditions. On average, the plants are under the snow for 4 months. This is a period when plants experience severe stress, both temperature and light. Therefore, by the end of winter, plants are weakened and can be affected by pathogens of Fusarium mold.

In general, triticale hybrids included in the PSI-2019 had high overwintering rates - on average, about $80-95 \%$ of plants were preserved in the plots by spring, which indicates a 4.5-5-point assessment of all samples for this indicator.

In 2019, in the spring after the snowfall, a small lesion of plants with Fusarium mold was observed. Nevertheless, the lesion was focal in nature, the spots with the mycelium of the fungus were mainly located in the micro-depressions of the relief left from poor-quality field preparation. In the spring, the snow came down early, which did not contribute to the development of Fusarium mold damage to winter crops. In general, the hybrid had very high values of resistance to this disease - 7-9 points [17].

The damage of the breeding numbers of winter triticale by leaf rust in 2019 was not noted.

Powdery mildew was found only in No. 2, resistance is 7 points. No symptoms of lesion were found in the remaining triticale samples.

Lodging is a negative sign that leads to difficulties, and sometimes the impossibility of crop harvesting. Dead plants dry out worse, as a result, the grain sprouts even in the ear before harvesting, is clogged with various pathogens, in particular, fusarias, which makes the grain unstable during storage and unsuitable for use for animal feed due to toxicity, because fusarias are toxin-forming fungi. Therefore, in triticale, as a relatively tall crop, creation of honeycombs resistant to lodging is performed [16].

The most reliable way to create lodging-resistant varieties is to reduce their height due to the introduction of low-stem genes. Both rye (dominant and recessive) and wheat (more than 20 Rht genes) have such genes. The combination of low-stem genes of the wheat and rye genomes leads to the creation of super-low-growing varieties. Nevertheless, triticale, like other crops, has a positive correlation between plant height, ear size and yield. Therefore, it is necessary to look for such combinations of low-stem genes that have little effect on plant productivity.

The evaluation of experimental triticale hybrids included in the preliminary variety testing in 2019 showed that they differed in plant height (Table 2).

Table 2. Grain yield, height and resistance to lodging of winter triticale varieties included in the PSI-2019

\begin{tabular}{|c|c|c|c|c|c|c|}
\hline No. & $\begin{array}{c}\text { Actual yield, } \\
\text { c/ha }\end{array}$ & $\begin{array}{c}\text { Difference } \\
\text { from the } \\
\text { standard } \\
\text { (c/ha) }\end{array}$ & Group & $\begin{array}{c}\text { Potential yield, } \\
\text { c/ha }\end{array}$ & $\begin{array}{c}\text { Plant } \\
\text { length, } \\
\text { cm }\end{array}$ & $\begin{array}{c}\text { Resistance } \\
\text { to lodging, } \\
\text { point }\end{array}$ \\
\hline 1 & 63.7 & -5.3 & 2 & 80.6 & 125 & 4 \\
\hline 2 & 68.3 & -0.7 & 2 & 105.0 & 115 & 4.5 \\
\hline 3 & 75.3 & +6.3 & 2 & 107.4 & 105 & 5 \\
\hline 4 & 76.4 & +7.4 & 2 & 104.3 & 100 & 4.5 \\
\hline 5 & 62.0 & -7.0 & 2 & 87.0 & 115 & 2 \\
\hline 6 & 72.4 & +3.4 & 2 & 91.9 & 90 & 5 \\
\hline 7 & 58.3 & -10.7 & 3 & 81.6 & 105 & 4.5 \\
\hline 8 & 69.0 & - & - & 95.0 & 120 & 3 \\
\hline 9 & 59.5 & -9.5 & 2 & 95.2 & 100 & 5 \\
\hline 10 & 65.4 & -3.6 & 2 & 80.3 & 110 & 3 \\
\hline 11 & 61.5 & -7.5 & 2 & 84.3 & 110 & 4 \\
\hline
\end{tabular}




\begin{tabular}{|c|c|c|c|c|c|c|}
\hline 12 & 62.3 & -6.7 & 2 & 90.8 & 115 & 4.5 \\
\hline 13 & 78.3 & +9.3 & 2 & 115.0 & 95 & 4.5 \\
\hline 14 & 75.5 & +6.5 & 2 & 101.0 & 95 & 5 \\
\hline 15 & 74.9 & +5.9 & 2 & 98.8 & 95 & 5 \\
\hline 16 & 76.2 & +7.2 & 2 & 98.1 & 95 & 4.5 \\
\hline 17 & 66.9 & -2.1 & 2 & 110.1 & 105 & 5 \\
\hline 18 & 46.9 & -22.1 & 3 & 63.6 & 125 & 2 \\
\hline 19 & 48.8 & -20.2 & 3 & 65.6 & 130 & 3 \\
\hline 20 & 51.8 & -17.2 & 3 & 79.6 & 125 & 2 \\
\hline 21 & 71.0 & +2.0 & 2 & 98.3 & 95 & 4.5 \\
\hline LSD $_{05}$ & 9.9 & - & - & - & - & - \\
\hline
\end{tabular}

Most of the tall samples (plant height above $120 \mathrm{~cm}$ ) had a different degree of lodging from a slight slope to almost complete lodging.

There are two types of lodging: stem, when the 2nd internode breaks off from above, and basal, when the entire stem lies under the weight of biomass, the place of bending is at the roots.

As can be seen from Table 2, a certain degree of lodging was noted even in the Timiryazevskaya 150 variety, which has always been characterized as stable. Nevertheless, in 2019, it had a completely different type of lodging than the other samples. All of them had basal lodging, and Timiryazevskaya 150 had stem lodging. Supposedly the cause was hail in the presence of a strong wind, which led to the breaking of the stems in the area of the intercalary meristem. This phenomenon led to partial breaking off the ears, which eventually reduced the grain yield.

The yield of the experimental triticale hybrids strongly depended on the lodging - it was greatly reduced in the lodged ones since the lodged areas were not harvested. The average yield for the nursery was $65.5 \mathrm{c} / \mathrm{ha}$. Nevertheless, none of the variety samples significantly exceeded the standard. All exceedances are within the limits of $\mathrm{LSD}_{05}$.

For a clear assessment of varietal samples in relation to the standard, Table 2 shows calculations of deviations of the actual yield from the standard and the assignment of the sample to any group. In the first column of the table, the yield of samples in $\mathrm{c} / \mathrm{ha}$ is indicated, in the second, the difference between the yield of the standard and the compared samples, in the third, the tested samples are ranked by groups relative to the value of the smallest significant difference: group 1 - samples that significantly exceed the standard in yield; group 2 - the yield of samples at the standard level, group 3 - the yield of varietal samples is significantly below the standard. Based on the data presented in Table 2, we can conclude that in the conditions of the growing season 2018-2019, all samples of winter triticale showed a relatively high yield, but there are no significantly more productive ones than the standard. The highest actual yield was noted in varietal samples No. 3, 4, 6, 13, 14 , 15, 16. Samples No. 7, 18, 19, 20 were the lowest-yielding. They were rejected in the process of further study.

The potential yield of triticale comtrol samples was determined by the tweezing method. It consists in the fact that in the middle of each plot of a certain variety type, pairs of morphologically similar ears are isolated. One ear is experimental - spikelets are removed from one side of the ear during the flowering phase. To facilitate the search for such an ear in sowing, it is marked with a bright thread. The second ear of the pair is the control. It is left without any impact, also marking with a bright thread of a different color. On each plot, 10 pairs of ears were allocated, a total of 40 ears were tweezed for each variety, and 40 ears were also subjected to control. The meaning of tweezing is to determine which grain is able to form a sample, if the entire pool of organic substances formed will not be distributed to all the flowers of the ear, but only half. Potential productivity is defined as twice grain weight of the tweezed ears. It is compared with the control and the percentage of increase 
that this variety could form under all favorable growing conditions is calculated. Tweezing allows to estimate the rate of reaction of various genotypes under certain environmental conditions [12].

After maturation, the ears were cut, the tweezed and control ears were threshed separately, the weight of the resulting grain was determined, the weight of 1000 grains were calculated and a comparison was made.

Table 2 shows the results of calculation of the potential yield of experimental triticale hybrids. The potential productivity of the standard - Nemchinovsky 56 exceeds the actual yield by $38 \%$, Timiryazevskaya 150 - by $27 \%$, line No. 2-by $54 \%$. Other varietal samples also stood out - No.3, No.4, No.13, No.14, No.15, No.17. They can be considered as intensive plastic samples. The remaining lines are characterized by greater stability of yield formation in various conditions of grain feeding, while forming a relatively high yield.

From the physical qualities of the grain, we estimated the weight of 1000 grains, the nature and percentage of sprouted grains (Table 3 ).

The actual weight of 1000 grains in almost all varieties ranged from $40 \mathrm{~g}$. The evaluation of this indicator in tweezed ears showed the potential size that each triticale variety can form in the created edaphic and meteorological conditions of the year. It can be seen that the potential of individual varieties exceeded the actual indicator by $30 \%$. Such samples can be considered plastic, capable of responding well to the improvement of vegetation conditions. Other varietal samples, among them - Timiryazeskaya 150 and Nemchinovsky 56 standard, showed the potential to increase the grain size in the range of $15-20 \%$. They can be considered stable over the years.

Grain nature is the weight of a certain volume of grain, usually 1 liter [14, 15]. It shows the degree of completion and density of the grain. The values of this indicator are different for different crops. Nevertheless, in the conditions of 2018-2019 in varietal samples No. 1, $2,6,13$, the values of grain nature are high, at the level of wheat, while in standard No. 8 significantly lower. The evaluation of the nature of the tweezed ears showed that with an increase in the grain size, the nature of the samples practically does not change. That is, the nature of grain is the most stable of all grain quality indicators, which characterizes the varietal sample in any cultivation conditions.

Table 3. Physical qualities of grain varietal samples of winter triticale, included in PSI-2019.

\begin{tabular}{|c|c|c|c|c|c|c|c|}
\hline No. & 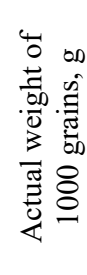 & 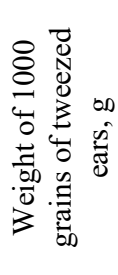 & 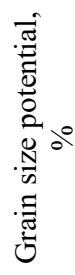 & 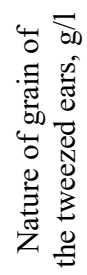 & 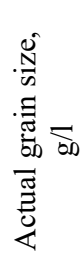 & 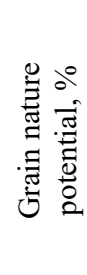 & 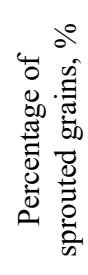 \\
\hline 1 & 41.2 & 46.8 & 114 & 746 & 755 & 99 & 4.0 \\
\hline 2 & 43.0 & 55.5 & 129 & 762 & 741 & 103 & 2.5 \\
\hline 3 & 42.0 & 52.2 & 124 & 738 & 723 & 102 & 12.5 \\
\hline 4 & 35.8 & 46.0 & 128 & 720 & 736 & 98 & 3.0 \\
\hline 5 & 45.2 & 59.1 & 131 & 722 & 705 & 102 & 11.0 \\
\hline 6 & 44.2 & $\begin{array}{l}50.8 \\
\end{array}$ & 115 & 774 & 750 & 103 & 1.3 \\
\hline 7 & 35.3 & 46.8 & 133 & 720 & 711 & 101 & 29.0 \\
\hline 8 & 40.2 & 49.5 & 119 & 731 & 697 & 105 & 1.5 \\
\hline 9 & 36.0 & 45.0 & 125 & 722 & 714 & 101 & 22.0 \\
\hline 10 & 44.0 & 54.7 & 124 & 724 & 694 & 104 & 6.0 \\
\hline 11 & 36.0 & 45.2 & 126 & 714 & 682 & 105 & 5.0 \\
\hline
\end{tabular}




\begin{tabular}{|c|c|c|c|c|c|c|c|}
\hline 12 & 40.9 & 49.0 & 120 & 739 & 731 & 101 & 22.0 \\
\hline 13 & 40.9 & 53.7 & 131 & 783 & 765 & 102 & 4.0 \\
\hline 14 & 39.8 & 47.7 & 120 & 726 & 720 & 101 & 11.0 \\
\hline 15 & 41.6 & 49.8 & 120 & 717 & 722 & 99 & 3.0 \\
\hline 16 & 42.2 & 51.1 & 121 & 735 & 706 & 104 & 1.8 \\
\hline 17 & 41.2 & 50.7 & 123 & 725 & 686 & 106 & 8.0 \\
\hline 18 & 44.1 & 51.3 & 116 & 730 & 725 & 101 & 2.0 \\
\hline 19 & 49.4 & 59.9 & 121 & 728 & 717 & 102 & 13.0 \\
\hline 20 & 46.6 & 54.2 & 116 & 734 & 722 & 102 & 8.0 \\
\hline 21 & 47.7 & 55.2 & 116 & 736 & 728 & 101 & 4.0 \\
\hline $\begin{array}{c}\text { Average } \\
\text { for } \\
\text { experiment }\end{array}$ & 41.8 & 51.1 & 122 & 734 & 720 & 102 & 8.3 \\
\hline LSD 05 & 2.3 & 2.5 & - & 27 & 25 & - & - \\
\hline
\end{tabular}

The percentage of sprouted grains (PSG) is a very important indicator that evaluates the sowing qualities of seeds, as well as the technological qualities of grain. Germination on the root can be hidden and explicit. Latent grain germination is expressed in the activation of hydrolases and the destruction of spare high-molecular compounds. At an early stage of this process, the grain has no visible changes. Latent germination of grain is evaluated by determining the autolytic activity. Then the phase of enzyme-mycotic depletion comes, when low-molecular organic substances are released from the grain and are lost. This usually occurs at high humidity, which is facilitated by precipitation and fog. The grain acquires external signs of run-off - the vitreousness is sharply reduced, the grain becomes dented, wrinkled, easily crushed by fingers. The next stage is when the embryo begins to increase in size and breaks through the grain shells. Then comes the phase of obvious germination of the grain on the root. In this case, the number of sprouted grains in the sample can be counted. For rye, GOST defines the limit of the presence of sprouted grains $-5 \%$. Since there are no other standards, we also accept $5 \%$ for triticale as the maximum permissible content of sprouted grain. Table 3 shows that the varietal samples No. 3, 5, 7, 9, $10,12,14,17,19$ and 20 have a high PSG. On this basis, the mentioned samples will be excluded from further study as unsuitable for cultivation in the central part of Russia. Nevertheless, there are breeding numbers with a low PSG - No. 6, 8 (standard) and 16. In the remaining samples, the degree of germination on the root can be determined as an average.

Table 4 shows an assessment of the biochemical qualities of the grain, studied varietal samples. Important indicators of grain quality are the protein content, which determines its feed value, the gluten content, which determines both its suitability for animal feeding and for use in baking. The state of the carbohydrate-amylase complex shows the degree of latent germination of grain.

The protein content in the grain of most triticale varietal samples ranged from $12-13 \%$. Only sample No. 15 was distinguished by high protein content $-14.7 \%$. This ensured the collection of vegetable protein of $11 \mathrm{c} / \mathrm{ha}$, which is significantly higher than that of other varieties.

Table 4. Biochemical properties of grain of triticale varietal samples included in PSI-2019.

\begin{tabular}{|c|c|c|c|}
\hline No. & $\begin{array}{c}\text { Protein content, } \\
\%\end{array}$ & Gluten content, \% & Falling number, $\mathrm{s}$ \\
\hline 1 & 12.9 & 15.0 & 93 \\
\hline 2 & 13.2 & 16.2 & 49 \\
\hline 3 & 12.3 & 13.4 & 50 \\
\hline 4 & 12.7 & 14.3 & 73 \\
\hline 5 & 13.0 & 15.9 & 52 \\
\hline
\end{tabular}




\begin{tabular}{|c|c|c|c|}
\hline 6 & 12.9 & 15.3 & 50 \\
\hline 7 & 12.8 & 13.9 & 54 \\
\hline 8 & 13.1 & 16.7 & 55 \\
\hline 9 & 13.1 & 15.4 & 46 \\
\hline 10 & 13.3 & 16.6 & 48 \\
\hline 11 & 12.1 & 13.2 & 68 \\
\hline 12 & 13.5 & 16.6 & 46 \\
\hline 13 & 11.7 & 11.8 & 58 \\
\hline 14 & 13.2 & 15.7 & 47 \\
\hline 15 & 14.7 & 20.1 & 48 \\
\hline 16 & 13.3 & 16.6 & 47 \\
\hline 17 & 13.6 & 18.0 & 54 \\
\hline 18 & 13.0 & 15.6 & 63 \\
\hline 19 & 13.3 & 16.5 & 58 \\
\hline 20 & 12.7 & 14.7 & 100 \\
\hline 21 & 12.4 & 13.9 & 50 \\
\hline $\begin{array}{c}\text { Average for } \\
\text { experiment }\end{array}$ & 13.0 & 15.5 & 57 \\
\hline LSD05 & 0.24 & 0.88 & 12.8 \\
\hline
\end{tabular}

The gluten content in the grain of the experimental triticale varieties varied within greater limits than the protein content - from 11.7 to $20 \%$. In general, according to the experiment, the gluten content was low, which positively characterizes the varieties as suitable for animal feeding. Only one variety sample No. 15 had a significantly higher gluten content than all the others. It is possible that this sample will be suitable for use in baking.

Table 5. Collection of vegetable protein from 1 hectare when cultivating varietal samples of winter triticale included in PSI-19.

\begin{tabular}{|c|c|c|c|}
\hline No. & Yield, c/ha & Protein content, $\%$ & Protein collection, c/ha \\
\hline 1 & 63.7 & 12.9 & 8.2 \\
\hline 2 & 68.3 & 13.2 & 9.0 \\
\hline 3 & 75.3 & 12.3 & 9.3 \\
\hline 4 & 76.4 & 12.7 & 9.7 \\
\hline 5 & 62.0 & 13.0 & 8.1 \\
\hline 6 & 72.4 & 12.9 & 9.3 \\
\hline 7 & 58.3 & 12.8 & 7.5 \\
\hline 8 & 69.0 & 13.1 & 9.0 \\
\hline 9 & 59.5 & 13.1 & 7.8 \\
\hline 10 & 65.4 & 13.3 & 8.7 \\
\hline 11 & 61.5 & 12.1 & 7.4 \\
\hline 12 & 62.3 & 13.5 & 8.4 \\
\hline 13 & 78.3 & 11.7 & 9.1 \\
\hline 14 & 75.5 & 13.2 & 9.9 \\
\hline 15 & 74.9 & 14.7 & 11.0 \\
\hline 16 & 76.2 & 13.3 & 10.1 \\
\hline 17 & 66.9 & 13.6 & 9.1 \\
\hline 18 & 46.9 & 13.0 & 6.1 \\
\hline 19 & 48.8 & 13.3 & 6.5 \\
\hline 20 & 51.8 & 12.7 & 6.6 \\
\hline 21 & 71.0 & 12.4 & 8.8 \\
\hline
\end{tabular}

The state of the carbohydrate-amylase complex of the grain was determined by the fallent number method. It can be seen that almost all triticale varietal samples had a strong degree of latent germination of grain - the fallen number did not reach $80 \mathrm{~s}$. Only in two 
samples - Timiryazevskaya 150 and No. 20, the autolytic activity of the grain can be attributed to satisfactory.

The characteristics of varietal samples of winter triticale for collecting protein from a hectare are shown in Table 5.

The analysis of the data shows that the greatest collection of vegetable protein per unit area is provided by varietal samples that combine high yield with an increased protein content in grain. Of the studied samples, these include No. 15 and No. 16.

\section{Conclusions}

As a result of a comprehensive assessment of the varietal samples in the preliminary variety testing, the most valuable samples of winter triticale were identified: $228 \mathrm{~h}$ (Castus x Don), which showed high potential productivity when combining a complex of other economically useful characteristics (high grain quality and resistance to major diseases); $287 \mathrm{~h}, 278 \mathrm{~h}-1,87 \mathrm{~h}-2,87 \mathrm{~h}-2$, and $278 \mathrm{~h}-2$ are characterized by high yield, low ability to germinate grain in the ear, resistance to diseases, etc. They are selected for further study.

A promising sample of winter triticale $228 \mathrm{~h}$, which has high indicators for a complex of economically valuable characteristics, is planned to be further transferred to the State variety testing.

\section{References}

1. M.S. Bazhenov, Triticale: Proceedings of the International Scientific and Practical Conference, 16-20 (2012)

2. N. Berkutova, E. Davydova, D. Berkutova, E. Buchma, Bread Products, 45-47 (2008)

3. N.S. Berkutova, Methods of evaluation and formation of grain quality, 206 (1991)

4. N.S. Berkutova, O.A. Buko, Evaluation and selection of grain crops for resistance to germination in the ear: review, 59 (1982)

5. State Register of Breeding Achievements approved for use, 516 (2019)

6. G.V. Gulyaev, Yu.L. Guzhov Breeding and seed production of field crops, 447 (1987)

7. L.I. Dolgodvorova Breeding of field crops for quality, 400 (1995)

8. B.A. Dospekhov, Methods of field experience, 238 (1979)

9. Yu.B. Konovalov, The causes of infertility in the ear of wheat and barley, 489 (1972)

10. Yu.N. Kotenko, V.S. Rubets, V.V. Pylnev, Proceedings of the Kuban State Agrarian University, 141-147 (2016)

11. Yu.N. Kotenko, V.S. Rubets, V.A. Korobkova, A.I. Yurkina, V.V. Pylnev, GNBS Bulletin, 108-114 (2019)

12. V.V. Pylnev, Yu.B. Konovalov, A.N. Berezkin, Workshop on breeding and seed production of field crops, 378 (2008)

13. M.G. Divashuk, N. Mayer, P.Yu. Krupin., V.S. Rubets, V.V. Pylnev, T.T.L. Nguen, A.A. Solovev, G.I. Karlov, Open Journal of Genetics, 51-55 (2012) DOI: 10.4236/ojgen.2012.21006

14. V. Rubets, I. Voronchikhina, V.Pylnev, Yu. Kotenko, A. Blinkov, E3S Web of conferences, 1043 (2021) DOI: 10.1051/e3sconf/202125401043

15. R. Różyło, J. Laskowski Polish Journal of Food and Nutrition Sciences, 61(1), 55-62 (2011) DOI: 10.2478 / v10222-011-0006-8 
16. I.N. Voronchikhina, V.V. Voronchikhin, V.S. Rubets, V.V. Pylnev. Triticale. Materials of the meeting of the triticale section of the OSKHN RAS, 97-101 (2021)

17. E.I. Gultyaeva, S.N. Sibikeev, A.E. Druzhin, E.L. Shaydayuk, Selskokh.biolog, 55(1), 27 (2020)

18. E.I. Gultyaeva, BIO Web of Conferences, 13 (2020) 